\title{
Analisis Video Views to Followers Ratio Tiktok Pada 5 Sepatu Brand Lokal Indonesia
}

\author{
I Wayan Agus Artha Kesuma (19101043) \\ agusartha540@gmail.com
}

\begin{abstract}
TikTok is a social media app launched by a Chinese company. TikTok allows users to create 15-second videos with music, filters, and other creative features. In Indonesia, there are 30.7 million active users, making Indonesia the country with the most TikTok users in the world. The large number of active TikTok users in Indonesia can certainly provide an opportunity for brands to make the TikTok platform a social media marketing platform. There are 5 Shoes Local Brand in Indonesia that use TikTok as a marketing platform, namely: Kodachi, Warrior, Getzke Footwear, Patrobas, and Johnson. The purpose of this study is to calculate the credibility of the TikTok account performance of the 5 Shoes Local Brand in Indonesia. The method used for this research is quantitative exploratory method. The results of this study indicate that the warrior brand shoes Indonesia is ranked first and has good account performance credibility.
\end{abstract}

\begin{abstract}
ABSTRAK
TikTok adalah aplikasi media sosial yang diluncurkan oleh perusahaan China. TikTok memungkinkan pengguna membuat video berdurasi 15 detik dengan musik, filter, dan fitur kreatif lainnya. Di Indonesia terdapat 30,7 juta pengguna aktif, menjadikan Indonesia negara pengguna TikTok terbanyak di dunia. Banyaknya pengguna aktif TikTok di Indonesia tentunya dapat memberikan peluang bagi brand untuk menjadikan platform TikTok sebagai platform pemasaran media sosial. Adapun 5 Sepatu Brand Lokal Indonesia yang memanfaatkan TikTok sebagai platform marketing, yaitu : Kodachi, Warrior, Getzke Footwear, Patrobas, dan Johnson. Tujuan dari penelitian ini yaitu untuk menghitung kredibilitas dari performa akun TikTok 5 Sepatu Brand Lokal Indonesia. Metode yang digunakan untuk penelitian ini yaitu metode eksploratif kuantitatif. Hasil dari penelitian ini menunjukan bahwa Sepatu Brand Warrior Indonesia mendapatkan peringkat pertama dan memiliki kredibilitas performa akun yang baik.
\end{abstract}

Keyword : Credibility Account TikTok ; Social Media Marketing ; Social Media TikTok ; Video Views to Followers Ratio ; Sepatu Brand Lokal Indonesia. 


\section{PENDAHULUAN}

Media sosial dapat digunakan sebagai penghubung suatu informasi dan komunikasi dari seorang produsen ke konsumen. Konsumen bisa mendapatkan informasi sebuah produk dari media sosial begitu juga sebaliknya. Produsen dapat memenuhi kebutuhan informasi konsumen dengan menggunakan media sosial. Seperti yang dikemukakan oleh Merril (2011), menyebutkan bahwa media sosial menjadi media yang potensial untuk menemukan konsumen atau pengguna produk dan membangun image merek produk. Media sosial merupakan salah satu system komunikasi yang memiliki fungsi : (1). Sebagai administrasi, (2). Media mendengarkan dan belajar, (3). Media berfikir dan melakukan perencanaan.(Dewa and Safitri 2021).

Salah satu aplikasi media sosial berbasis audio visual yang banyak diminati saat ini adalah TikTok. Aplikasi TikTok banyak diminati oleh remaja karena menghibur, juga membantu meningkatkan kreativitas dalam mengedit dan membuat sebuah konten video yang menarik perhatian publik, tetapi tak jarang juga aplikasi ini membuat para remaja menjadi lupa akan waktu dan tempat dalam menggunakannya. Aplikasi ini pun membuat penggunanya menjadi berlomba-lomba untuk viral, bahkan demi mendapatkan respon dan likes yang banyak, mereka rela melakukan hal apa saja. Aplikasi TikTok tidak hanya menarik perhatian anak remaja melainkan orang dewasa. Saat ini pengguna TikTok juga berasal dari selebriti lokal dan mancanegara bahkan pejabat dan beberapa perusahaan juga menggunakan aplikasi audio visual ini.(Chandra Kusuma and Oktavianti 2020).

Kehadiran media sosial TikTok dapat membangun sebuah brand, TikTok juga dapat membangun personal branding pemiliknya (Ishihara and Oktavianti 2021). Di Indonesia, terdapat 30,7 juta pengguna TikTok yang aktif sehingga menjadikan Indonesia sebagai negara dengan pengguna TikTok terbesar di dunia. Maraknya jumlah pengguna TikTok aktif di Indonesia tentu dapat memberikan peluang bagi brand untuk menjadikan platform ini sebagai platform social media marketing. Cukup banyak akun perushaan-perusahaan yang ada pada tiktok, contohnya seperti sepatu brand lokal Indonesia. Adapun 5 Sepatu Brand Lokal Indonesia, diantaranya yaitu : Kodachi, Warrior, Getzke Footwear, Patrobas, Johnson ("5 Sepatu Brand Lokal Indonesia Dengan Harga Di Bawah Rp 300.000 - Pikiran-Rakyat.Com” n.d.).

Penelitian ini menggunakan metode eksploratif kuantitatif, dan akan menghitung menggunakan rasio-rasio yang ada pada TikTok. Pada penelitian (Permana and Meinarni 2021) menjelaskan bahwa terdapat 17 rasio yang ada pada sosial media TikTok dan relevan digunakan sebagai media ukur kredibilitas akun yang ada. Penelitian ini hanya berfokus untuk menghitung kredibilitas Video Views to Followers Ratio pada 5 Sepatu Brand Lokal Indonesia. Adapun 5 Sepatu Brand Lokal Indonesia, diantaranya yaitu : Kodachi, Warrior, Getzke Footwear, Patrobas, Johnson ("5 Sepatu Brand Lokal Indonesia Dengan Harga Di Bawah Rp 300.000 - Pikiran-Rakyat.Com" n.d.). Tujuan dari penelitian ini adalah mengetahui kredibilitas performa dari akun TikTok 5 Sepatu Brand Lokal Indonesia menggunakan Video Views to Followers Ratio. 


\section{TINJAUAN PUSTAKA}

Kekuatan media sosial menjadi penting untuk membangun relasi dengan khalayak atau konsumen. Produk yang dihasilkan oleh media tradisional tidak lagi tertumpu pada media itu sendiri, namun baik secara utuh maupun sebagian akan muncul di media sosial dan menjadi perbincangan. Dalam perspektif kritis, perbincangan sebuah produk akan mengarahkan khalayak lain terhadap konten tersebut. Pada akhirnya, khalayak yang pada awalnya hanya mengonsumsi informasi dari getok tular kemudian menjadi konsumen produk dan tahap selanjutnya bisa jadi konsumen itu sendiri yang akan menyebarkan pengalamannya di media sosial.(Nasrullah Program Studi Magister Komunikasi dan Penyiaran Islam Fakultas Ilmu Dakwah dan Ilmu Komunikasi UIN Syarif Hidayatullah, Jalan Ir Djuanda No, and Selatan n.d.)

Tik Tok merupakan salah satu aplikasi yang paling terpopuler dan diminati di dunia. Tik Tok memungkinkan penggunanya membuat video berdurasi 15 detik disertai musik, filter, dan beberapa fitur kreatif lainnya. Aplikasi ini diluncurkan oleh perusahaan asal Tiongkok, China, ByteDance pertama kali meluncurkan aplikasi yang memiliki durasi pendek yang bernama Douyin. Hanya dalam waktu 1 tahun, Douyin memiliki 100 juta pengguna dan 1 miliar tayangan video setiap hari. Popularitas Douyin yang tinggi membuatnya melakukan perluasan ke luar China dengan nama Tik Tok. Menurut laporan dari Sensor Tower, aplikasi ini diunduh 700 juta kali sepanjang tahun 2019. Hal ini membuat Tik Tok dapat mengungguli sebagian aplikasi yang berada dibawah naungan Facebook Inc. aplikasi ini menempati peringkat ke dua setelah Whatsapp yang memiliki 1,5 miliar pengunduh(Adawiyah and Adawiyah 2020)

Aplikasi Tiktok merupakan suatu bentuk media baru yang berfungsi untuk menyediakan dukungan berupa fitur edit seperti lagu dan efek pada wajah dalam pembuatan video berdurasi 30-60 detik, Seiring dengan meningkatnya popularitas Tiktok di tahun 2019, seorang remaja bernama Prabowo Mondardo atau lebih dikenal dengan akun Instagramnya @bowo_allpennliebe menjadi viral di Indonesia. Konten video yang dipublikasi di akun Instagramnya berasal dari Tiktok.(Ruth and Candraningrum 2020). 
Aplikasi TikTok tidak hanya digunakan untuk membuat konten video dengan tujuan menghibur pengguna lainnya. Aplikasi TikTok juga dapat dijadikan peluang bagi brand atau perusahaan sebagai platform social media marketing. Penelitian (Purnamasari and Tutiasri 2021) menyatakan bahwa TikTok berpengaruh positif dan signifikan terhadap minat beli atau berbelanja secara online. Sehingga dengan ini, TikTok mampu memberikan peluang yang sangat tinggi bagi perusahaan-perusahaan dalam melakukan digital marketing.

TikTok dirasakan memiliki kekuatan ataupun pengaruh dalam industri, sehingga menimbulkan kualitas akun yang menentukan strata maupun kredibilitas pemilik akun. Kredibilitas akun TikTok merupakan suatu hal yang cukup penting untuk berbagai kepentingan. Kredibilitas sebuah akun TikTok dapat diukur dari tingkat performa yang dihasilkan secara matematis. Dalam mengukur performa diperlukan skala pengukuran yang tertuang ke dalam rasio. 


\section{METODE PENELITIAN}

Penelitian ini menggunakan metode eksploratif kuantitatif untuk mengetahui kredibilitas dari performa akun TikTok Sepatu Brand Lokal Indonesia. Metode eksploratif adalah metode penelitian yang bertujuan untuk melakukan eksplorasi pengetahuan ataupun ide-ide baru mengenai suatu hal yang baru, agar nantinya dapat merumuskan permasalahan secara terperinci (Maryam, Isrok'atun, and Aeni 2016).

Tujuan penelitian ini yaitu untuk mengetahui nilai kredibillitas dari performa akun TikTok 5 Sepatu Brand Lokal Indonesia. Terdapat beberapa langkah yang wajib dilakukan dalam penelitian ini, sehingga nantinya mampu menemukan peringkat pertama akun TikTok Sepatu Brand Lokal Indonesia yang memiliki performa terbaik. Langkah-langkah yang dilakukan diantaranya adalah:

\section{Melakukan Eksplorasi Pada Website Untuk Menentukan Objek yang Akan Dianalisa.}

Eksplorasi ini hanya dilakukan pada beberapa halaman website saja, yang hanya menyediakan informasi mengenai objek yang di teliti saja. Setelah ekslorasi telah dilakukan, maka nantinya akan ditemukan nama-nama sepatu brand lokal di Indonesia yang nantinya akan dijadikan objek analisa. Saat sudah melakukan eksplorasi pada halaman website, langkah selanjutnya adalah mencari nama akun TikTok dari masingmasing sepatu brand lokal indonesia. Karena Analisa ini berpacu pada sosial media TikTok, maka harus dipastikan terlebih dahulu semua brand memiliki akun pada aplikasi sosial media TikTok.

\section{Menghitung Nilai Rata-Rata Variable Dari 5 Sepatu Brand Lokal Indonesia.}

Pada langkah ini dilakukan penghitung nilai variable video views dan variable followers. Variabel adalah sesuatu yang memiliki nilai, dimana nilai tersebut bervariasi, sehingga nilai tersebut dapat dijadikan sebagai dasar untuk empat data yang berbeda seperti rasio, skala, ordinal, nominal dan internal (Rankuti 2015). Cara untuk menghitung nilai rata-rata dari variabel video views dan variable followers adalah : 
- Untuk variabel video views yaitu dengan cara mengambil minimal 10 postingan kemudian di hitung untuk menemukan nilai rata-rata dari variabel video views.

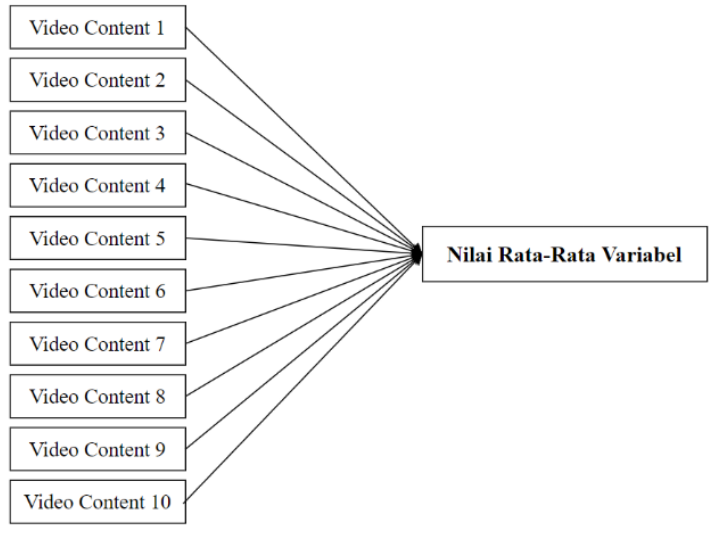

Gambar 1. Analisa Nilai Rata-Rata Variabel.

- Sedangkan untuk variable followers hanya perlu mengecek berapa followers dari akun TikTok dari masing-masing sepatu brand lokal Indonesia

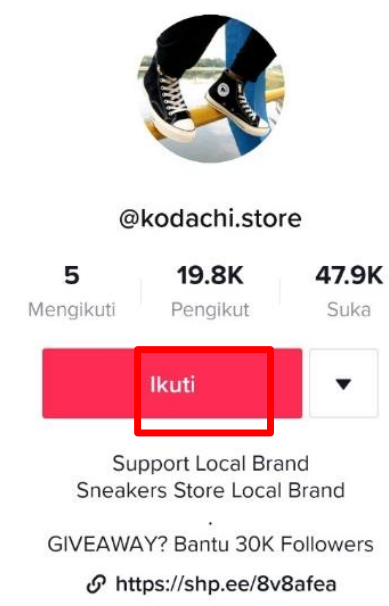

Gambar 2. Analisa Nilai Variabel Followers. 


\section{Menghitung Nilai Kredibilitas Rasio}

Untuk menghitung nilai kredibilitas dari video views to followers ratio., peneliti menggunakan cara membagi nilai variabel pertama dengan nilai variabel kedua. Jika video views memiliki nilai rata rata 100 dan memiliki followers 300, maka cara menghitungnya yaitu $100: 300=0,3$. Dengan demikian nilai dari video views to followers ratio adalah 0,3 .

\section{Menentukan Peringkat Pada Akun TikTok}

Langkah terakhir yang dilakukan adalah menentukan peringkat pada masing-masing rasio yang ada. Saat penentuan peringkat ini perlu melihat karakteristik dari rasio yang di teliti. Jika karakteristik rasio tergolong rendah, maka nantinya objek yang memiliki nilai terendah akan mendapatkan angka 5 dan objek yang memiliki nilai tertinggi akan mendapatkan angka 1. Namun jika rasio memiliki tergolong karakteritik tinggi maka akan berbanding terbalik dengan sebelumnya yaitu objek yang mendapatkan nilai tinggi akan mendapatkan angka 5 dan objek yang mendapatkan nilai terendah akan mendapatkan angka 1. Setelah mendapatkan hasil kredibilitas ratio maka dapat disimpulkan objek yang mana mendapatkan peringkat 1 sampai dengan peringkat 5 . 


\section{HASIL DAN PEMBAHASAN}

Akun TikTok dari 5 Sepatu Brand Lokal Indonesia, diantaranya :

\section{Kodachi}

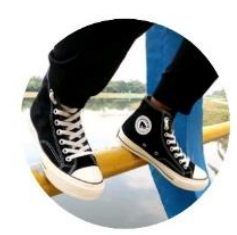

@kodachi.store

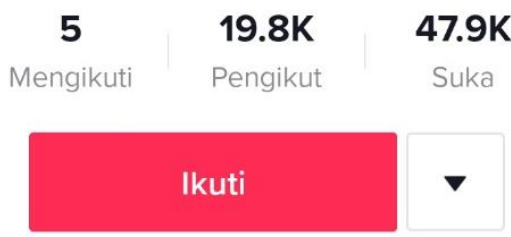

Support Local Brand Sneakers Store Local Brand

\section{GIVEAWAY? Bantu 30K Followers}

$\mathcal{O}$ https://shp.ee/8v8afea

Gambar 1. Akun TikTok Kodachi

Sumber : https://www.tiktok.com/@kodachi.store (akses pada 21-10-2021)

\section{Warrior}

\section{WARRIOR}

\section{@warriorshoes}

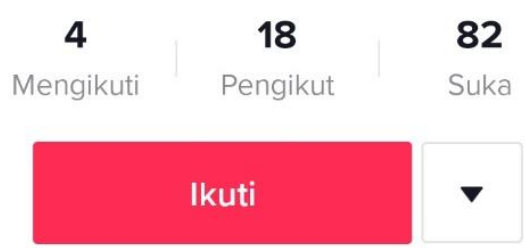

Gambar 2. Akun TikTok Warrior

Sumber : https://www.tiktok.com/@warriorshoes (akses pada 21-10-2021) 


\section{Getzke Footwear}

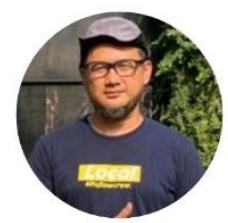

@mr.getzke

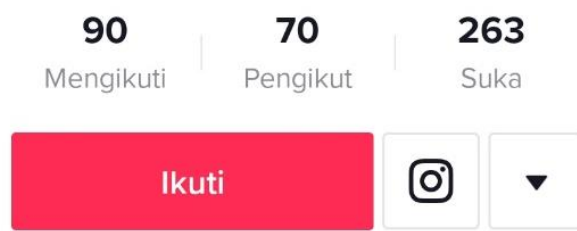

Gambar 3. Akun TikTok Getzke Footwear

Sumber : https://www.tiktok.com/@mr.getzke (akses pada 21-10-2021)

\section{Patrobas}

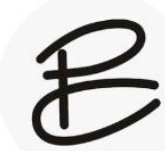

@patrobas.id

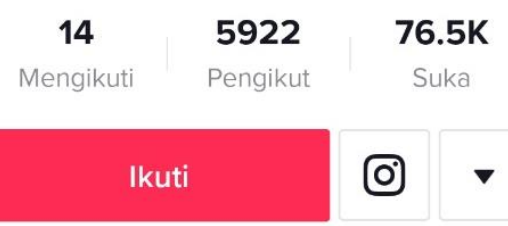

Price \& Benefit. Sepatu vulcanized berkualitas harga terjangkau $\downarrow$ Order klik $\downarrow$

$\mathcal{O}$ https://patrobas.id/links/ $\square$ Email

? Tanya Jawab

Gambar 4. Akun Tiktok Patrobas

Sumber : https://www.tiktok.com/@patrobas.id (akses pada 21-10-2021) 


\section{Johnson}

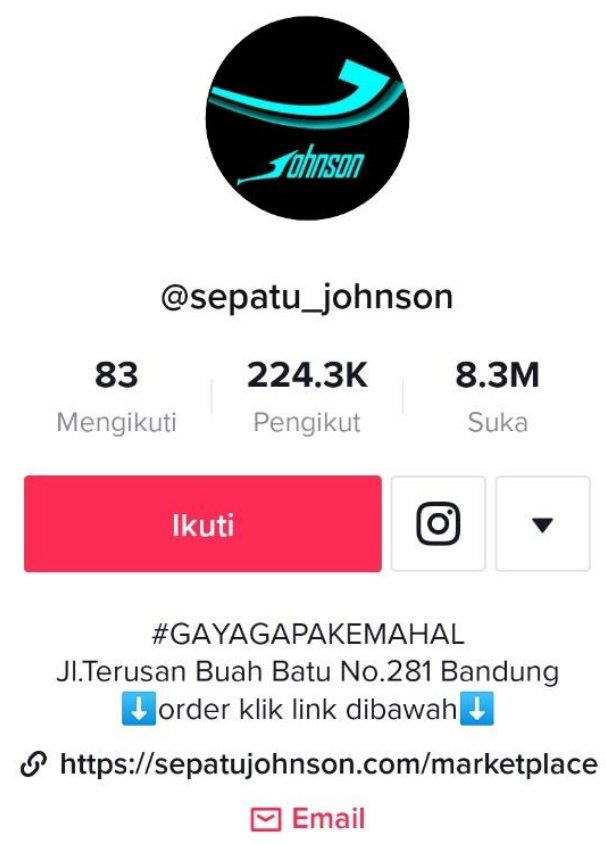

Gambar 5. Akun TikTok Johnson

Sumber : https://www.tiktok.com/@sepatu_johnson (akses pada 21-10-2021)

Dari kelima akun TikTok Sepatu Brand Lokal Indonesia, peneliti menemukan nilai dari masing-masing variabel yang ada untuk menghitung rasio Video Views to Followers dari setiap akun. Pada akun TikTok terdapat 7 variabel, diantaranya yaitu :

1. Likes

2. Followers

3. Following

4. Video Likes

5. Video Comments

6. Video Share

7. Video Views

Dari ketujuh variabel tersebut peneliti hanya fokus untuk menemukan hasil dari 2 variabel, yaitu :

1. Video Views

2. Followers

Dari kedua variabel tersebut kemudian dianalisa sehingga menemukan nilai rata-rata dari variabel video views dan variabel followers. Untuk menghitung nilai rata-rata dari variabel video views dan variabel followers yaitu dengan cara mengambil minimal 10 postingan kemudian di hitung sehingga menemukan nilai rata-rata dari masing-masing variabel. Berikut merupakan tabel nilai rata-rata dari masing-masing Sepatu Brand Lokal Indonesia, yaitu : 
Tabel 1. Analisa Nilai Rata-Rata Nilai Variabel Video Views dan Followers Akun TikTok Kodachi

\begin{tabular}{|c|c|c|}
\hline \multicolumn{3}{|c|}{ Kodachi } \\
\hline NO & Video Views & Followers \\
\hline 1 & 458 & \\
\hline 2 & 689 & \\
\hline 3 & 2378 & \\
\hline 4 & 1399 & \\
\hline 5 & 1459 & \multirow{2}{*}{19800} \\
\hline 6 & 374 & \\
\hline 7 & 612 & \\
\hline 8 & 545 & \\
\hline 9 & 1413 & \\
\hline 10 & 386 & \\
\hline TOTAL & $\mathbf{9 7 1 . 3}$ & \\
\hline
\end{tabular}

Sumber : Pengolah Data Excel

Tabel 2. Analisa Nilai Rata-Rata Nilai Variabel Video Views dan Followers Akun TikTok Warrior

\begin{tabular}{|c|c|c|}
\hline \multicolumn{3}{|c|}{ Warior } \\
\hline NO & Video views & Followers \\
\hline 1 & 234 & \\
\hline 2 & 104 & \\
\hline 3 & 116 & \\
\hline 4 & 112 & \\
\hline 5 & 7346 & \multirow{2}{*}{18} \\
\hline 6 & 566 & \\
\hline 7 & 736 & \\
\hline 8 & 637 & \\
\hline 9 & 633 & \\
\hline 10 & 55900 & \\
\hline TOTAL & $\mathbf{6 6 3 8 . 4}$ & \\
\hline
\end{tabular}

Sumber : Pengolah Data Excel 
Tabel 3. Analisa Nilai Rata-Rata Nilai Variabel Video Views dan Followers Akun TikTok Getzke Footwear

\begin{tabular}{|c|c|c|}
\hline \multicolumn{3}{|c|}{ Getzke Footwear } \\
\hline NO & Video views & Followers \\
\hline 1 & 48 & \\
\hline 2 & 51 & \\
\hline 3 & 53 & \\
\hline 4 & 66 & \\
\hline 5 & 64 & \multirow{2}{*}{6} \\
\hline 6 & 83 & \multirow{3}{*}{} \\
\hline 7 & 75 & \\
\hline 8 & 64 & \\
\hline 9 & 82 & \\
\hline 10 & 62 & \\
\hline TOTAL & $\mathbf{6 4 . 8}$ & \\
\hline
\end{tabular}

Sumber : Pengolah Data Excel

Tabel 4. Analisa Nilai Rata-Rata Nilai Variabel Video Views dan Followers Akun TikTok Patrobas

\begin{tabular}{|c|c|c|}
\hline \multicolumn{3}{|c|}{ Patrobas } \\
\hline \multicolumn{3}{|c|}{} \\
\hline NO & Video views & Followers \\
\hline 1 & 530 & \\
\hline 2 & 37100 & \\
\hline 3 & 1577 & \\
\hline 4 & 17900 & \\
\hline 5 & 11600 & \multirow{3}{*}{5057} \\
\hline 6 & 951 & \\
\hline 7 & 1006 & \\
\hline 8 & 1005 & \\
\hline 9 & 1008 & \\
\hline 10 & 44300 & \\
\hline TOTAL & $\mathbf{1 1 6 9 7 . 7}$ & \\
\hline
\end{tabular}

Sumber : Pengolah Data Excel 
Tabel 5. Analisa Nilai Rata-Rata Nilai Variabel Video Views dan Followers Akun TikTok Johnson

\begin{tabular}{|c|c|c|}
\hline \multicolumn{3}{|c|}{ Johnson } \\
\hline NO & Video views & Followers \\
\hline 1 & 45100 & \multirow{11}{*}{216100} \\
\hline 2 & 1421 & \\
\hline 3 & 7208 & \\
\hline 4 & 38800 & \\
\hline 5 & 4988 & \\
\hline 6 & 39500 & \\
\hline 7 & 5140 & \\
\hline 8 & 5842 & \\
\hline 9 & 12200 & \\
\hline 10 & 4322 & \\
\hline TOTAL & 16452.1 & \\
\hline
\end{tabular}

Sumber : Pengolah Data Excel

Setelah menghitung nilai rata-rata tersebut, maka akan menemukan hasil akhir nilai rata-rata dari variabel video views dan followers

Tabel 6. Nilai Variabel Pada 5 Akun TikTok Sepatu Brand Lokal Indonesia

\begin{tabular}{|l|c|c|c|c|c|}
\hline Variable & Kodachi & Warior & Getzke Footwear & Patrobas & Johnson \\
\hline Video views & 971.3 & 6638.4 & 64.8 & 11697.7 & 16452.1 \\
\hline Followers & 19800 & 18 & 69 & 5857 & 216100 \\
\hline \multicolumn{7}{|c|}{ Sumber : Pengolah Data Excel }
\end{tabular}

Pada akun TikTok terdapat 17 rasio yang relevan digunakan untuk mengukur kredibilitas pada masing-masing akun. Namun pada penelitian kali ini hanya berfokus untuk menghitung Video Views to Followers Ratio. Untuk menghitung kredibilitas dari masing-masing akun TikTok setiap brand sepatu lokal Indonesia, peneliti menghitung dengan cara : variabel 1 akan dibagi dengan variabel 2, sehingga ditemukan hasil analisisa dari rasio tersebut.

Tabel 7. Hasil Perhitungan Rasio Akun TikTok

\begin{tabular}{|c|c|c|c|c|c|c|}
\hline No & RATIO & Kodachi & Warrior & Getzke Footwear & Patrobas & Johnson \\
\hline 1 & $\begin{array}{l}\text { Video Views to } \\
\text { Followers Ratio }\end{array}$ & 0.04905556 & 368.80000000 & 0.93913043 & 1.99721701 & 0.07613188 \\
\hline
\end{tabular}


Video Views to Followers Ratio memiliki karakteristik yang tinggi, artinya semakin tinggi nilai yang dihasilkan maka semakin baik kredibilitas dari performa akun tersebut. Untuk memberikan peringkat pada masing-masing Sepatu Brand Lokal Indonesia, peneliti memberikan angka 5 kepada brand yang mendapatkan nilai tertinggi dan angka 1 untuk brand yang mendapatkan nilai terendah. Berikut merupakan tabel urutan nilai yang dihasilkan oleh masing-masing sepatu brand lokal indonesia.

Tabel 8. Nilai Rasio Akun TikTok 5 Sepatu Brand Lokal Indonesia

\begin{tabular}{|l|c|c|c|c|c|}
\hline \multirow{2}{*}{ RATIO } & \multicolumn{5}{|c|}{ NILAI } \\
\cline { 2 - 6 } & Kodachi & Warrior & $\begin{array}{l}\text { Getzke } \\
\text { Footwear }\end{array}$ & Patrobas & Johnson \\
\hline $\begin{array}{l}\text { Video Views to } \\
\text { Followers Ratio }\end{array}$ & 1 & 5 & 3 & 4 & 2 \\
\hline
\end{tabular}

Sumber : Pengolah Data Excel

Dari Tabel Nilai Rasio Akun TikTok 5 Sepatu Brand Lokal Indonesia dapat simpulkan bahwa Warrior mendapatkan nilai tertinggi untuk rasio Video Views to Followers. Sedangkan akun TikTok Kodachi mendapatkan nilai terendah untuk rasio ini. Jadi, pada penelitian ini Warrior memiliki kredibilitas performa yang lebih baik dibandingkan dengan brand sepatu lokal yang lainnya.

\section{KESIMPULAN}

Tujuan dari penelitian ini adalah mengetahui kredibilitas performa dari akun TikTok 5 Sepatu Brand Lokal Indonesia menggunakan Video Views to Followers Ratio. 5 Sepatu Brand Lokal Indonesia tersebut diantaranya : Kodachi, Warrior, Getzke Footwear, Patrobas, dan Johnson. Dari kelima sepatu brand lokal tersebut dapat disimpulkan bahwa :

1. Peringkat pertama diraih oleh brand Warrior Indonesia dengan nilai tertinggi yaitu 368.80000000

2. Peringkat kedua diraih oleh brand Patrobas Indonesia dengan nilai 1.99721701

3. Peringkat ketiga diraih oleh brand Getzke Footwear Indonesia dengan nilai 0.93913043

4. Peringkat keempat diraih oleh brand Johnson Indonesia dengan nilai 0.07613188

5. Peringkat kelima diraih oleh brand Kodachi Indonesia dengan nilai terendah yaitu 0.04905556 


\section{DAFTAR PUSTAKA}

Adawiyah, Dwi Putri Robiatul. 2020. "Pengaruh Penggunaan Aplikasi TikTok Terhadap Kepercayaan Diri Remaja Di Kabupaten Sampang.” Jurnal Komunikasi 14 (2): 135-48. https://doi.org/10.21107/ilkom.v14i2.7504.

"5 Sepatu Brand Lokal Indonesia Dengan Harga Di Bawah Rp 300.000 - PikiranRakyat.Com.” n.d. Accessed October 27, 2021. https://www.pikiranrakyat.com/belia/pr-01332522/5-sepatu-brand-lokal-indonesia-dengan-harga-di-bawahrp-300000.

Ishihara, Yemikaori Yumna Ulya, and Roswita Oktavianti. 2021. "Personal Branding Influencer Di Media Sosial TikTok.” Koneksi 5 (1): 76-82. https://doi.org/10.24912/KN.V5I1.10162.

Adawiyah, Dwi, and Dwi Putri Robiatul Adawiyah. 2020. "Pengaruh Penggunaan Aplikasi TikTok Terhadap Kepercayaan Diri Remaja Di Kabupaten Sampang.” Jurnal Komunikasi 14 (2): 135-48. https://doi.org/10.21107/ilkom.v14i2.7504.

Chandra Kusuma, Dian Novita Sari, and Roswita Oktavianti. 2020. "Penggunaan Aplikasi Media Sosial Berbasis Audio Visual Dalam Membentuk Konsep Diri (Studi Kasus Aplikasi Tiktok).” Koneksi 4 (2). https://doi.org/10.24912/kn.v4i2.8214.

Dewa, Chriswardana Bayu, and Lina Ayu Safitri. 2021. "Pemanfaatan Media Sosial Tiktok Sebagai Media Promosi Industri Kuliner Di Yogyakarta Pada Masa Pandemi Covid-19 (Studi Kasus Akun TikTok Javafoodie).” Khasanah Ilmu - Jurnal Pariwisata Dan Budaya 12 (1). https://doi.org/10.31294/khi.v12i1.10132.

Nasrullah Program Studi Magister Komunikasi dan Penyiaran Islam Fakultas Ilmu Dakwah dan Ilmu Komunikasi UIN Syarif Hidayatullah, Rulli, Jakarta H Jalan Ir Djuanda No, and Tangerang Selatan. n.d. "BLOGGER DAN DIGITAL WORD OF MOUTH: GETOK TULAR DIGITAL ALA BLOGGER DALAM KOMUNIKASI PEMASARAN DI MEDIA SOSIAL BLOGGER AND DIGITAL WORD OF MOUTH: A DIGITAL METHOD OF BLOGGERS IN MARKETING COMMUNICATION IN SOCIAL MEDIA.” Accessed November 2, 2021. 
Purnamasari, Nurjihan Pricillia, and Ririn Puspita Tutiasri. 2021. "Analisis Resepsi Remaja Perempuan Terhadap Gaya Hidup Berbelanja Fashion Melalui Tayangan Video 'Belanja Gak Aturan’ Dalam Akun Tiktok @handmadeshoesby.”Jurnal Representamen 7 (01). https://doi.org/10.30996/REPRESENTAMEN.V7I01.5129.

Ruth, Debra, and Diah Ayu Candraningrum. 2020. "Pengaruh Motif Penggunaan Media Baru Tiktok Terhadap Personal Branding Generasi Milenial Di Instagram.” Koneksi 4 (2): 207-14. https://journal.untar.ac.id/index.php/koneksi/article/view/8093.

Rankuti, Freddy. 2015. “Buku Riset Pemasaran.” 2015.

Maryam, Siti, Isrok'atun Isrok'atun, and Ani Nur Aeni. 2016. 'PENDEKATAN EKSPLORATIF UNTUK MENINGKATKAN KEMAMPUAN REPRESENTASI MATEMATIS DAN KEPERCAYAAN DIRI SISWA.” Jurnal Pena Ilmiah 1 (1): 55160. https://doi.org/10.23819/PI.V1I1.2984. 